\title{
Serum levels of Cadmium, Calcium, Lead and Iron in Schizophrenic Patients
}

\author{
Pinky Karim¹, Md. Iqbal Hossain ${ }^{2}$, A. F. M. Nazmus Sadat ${ }^{1}$, Zabun Nahar ${ }^{2}$, \\ Md. Khalid Hossain ${ }^{3}$ and Abul Hasnat ${ }^{2}$ \\ ${ }^{1}$ Department of Pharmacy, University of Asia Pacific, Dhanmondi, Dhaka, Bangladesh \\ ${ }^{2}$ Department of Clinical Pharmacy and Pharmacology, Faculty of Pharmacy, University of Dhaka, \\ Dhaka-1000, Bangladesh \\ ${ }^{3}$ Department of Pharmaceutical Chemistry, Faculty of Pharmacy, University of Dhaka, \\ Dhaka-1000, Bangladesh
}

\begin{abstract}
The serum concentration of cadmium $(\mathrm{Cd})$, lead $(\mathrm{Pb})$, calcium $(\mathrm{Ca})$ and iron $(\mathrm{Fe})$ in 30 schizophrenic patients and 30 normal healthy subjects were analyzed by flame atomic absorption spectroscopy. The concentrations of $\mathrm{Cd}, \mathrm{Pb}$ and $\mathrm{Ca}$ in schizophrenic disorder patients was not increased significantly $(\mathrm{P}>0.05)$ compared to that of the cohort controls. But the concentration of $\mathrm{Fe}$ in schizophrenic patients was significantly different from that of the cohort control $(\mathrm{p}<0.000)$. The change in serum concentration of different trace elements may have some prognostic significance for the diagnosis of schizophrenic disorder. However further work is suggested to examine the exact correlation between trace elements level and the degree of disorder in schizophrenic patients.
\end{abstract}

Key words: Schizophrenic patients, trace elements, clinical significance

\section{INTRODUCTION}

Schizophrenia is a psychiatric disorder denoting a persistent, often chronic, mental illness variously affecting behaviour, thinking, and emotion. The term schizophrenia comes from the Greek words schizo means split or divide and phrenos means mind. ${ }^{1}$ This rarely treated psychotic disorder strikes primarily teenagers and young adults, leading to severe psychological disability during the potentially creative and productive life.

Trace elements are required for numerous metabolic and physiological processes in the human body. ${ }^{2}$ They play a part in the synthesis and structural stabilization of both proteins and nucleic acids.

Correspondence to: Abul Hasnat

Tel: +880-2-8612069; Fax: +880-2-8615583

E-mail: ahasnat99@yahoo.com

Dhaka Univ. J. Pharm. Sci. 5(1-2): 9-13, 2006 (June-December)
Therefore, imbalances in the optimum levels of trace elements may adversely affect biological processes, and are associated with many diseases. ${ }^{3}$

Schizophrenia and related disorders are adultonset illnesses with no definitively established risk factors. Several studies report that exposures to infection and nutritional deprivation during early development may increase the risk of developing schizophrenia.

Prenatal and neonatal toxic metal exposure as well as chronic exposures to lead, arsenic, cadmium, aluminum etc. have been documented to cause common and widespread neurological and psychological effects including depression, anxiety, mood disorders, schizophrenia, anorexia, cognitive impairments, seizures, etc. ${ }^{4,5}$ Trace elements play a vital role in immune system and is essential for the 
optimal function of a variety of biochemical and physiological processes. ${ }^{6}$

Iron $(\mathrm{Fe})$, apart from its presence in all body cells, plays a role in the oxygenation of tissues as it is incorporated in the haem structure of haemoglobin. Low serum iron has been reported in a variety of neuropsychiatric motor disorders. ${ }^{7}$ Low level of iron affects dopaminergic system. Many researchers found abnormal iron deposits in the brains of schizophrenics. ${ }^{8}$ Lead, an undisputed neurotoxin, may affect numerous cell functions, including the release of neurotransmitters such as dopamine and serotonin. Lead toxicity is responsible for ADD (Attention Deficit Disorder). ${ }^{9}$

Any sort of disorder (negative or positive) in the concentration level of these trace elements may help in developing psychiatric disorders. For instance, it was found that plasma $\mathrm{Fe}$ concentration was significantly lower $(p<0.05)$ in schizophrenic patients than in controls. ${ }^{10}$ It is suggested that $\mathrm{Ca}$ is capable of inducing structural and cognitive deficits seen in schizophrenia and it has been proposed that altered $\mathrm{Ca}$ signaling may constitute the central unifying molecular pathology in schizophrenia. ${ }^{11}$ This can suggest that alterations in essential trace elements may play a role in the pathogenesis of neurological and psychiatric diseases.

As no work has been reported regarding trace element concentrations of cadmium, calcium and other elements in schizophrenic patients, this work was undertaken to find out the relationship between trace element level and degree of disorder, if any.

\section{MATERIALS AND METHODS}

Thirty patients comprising of 24 males and 6 females were diagnosed according to DSM-IV (Diagnostic and Statistical Manual for Mental Disorders, Fourth Edition) as having schizophrenia disorder and were recruited. Patients were recruited randomly from Dhaka Medical College Hospital, Bangladesh Medical College Hospital, BSMMU and National Mental Institute. Thirty healthy volunteers comprising of 25 males and 5 females were recruited as control.

Both groups were interviewed and asked to complete a questionnaire concerning their use of drugs, including use of any diabetes medication or steroids, smoking or other habits that could affect the outcome of the results. Patients and controls were categorized in terms of occupation such as service holder, housewife, laborer, and businessman or other. Two psychiatrists gave all the patients and control volunteers a routine physical check up including their organ activity, weight, nutritional condition and blood pressure. The study subjects were briefed about the purpose of the study and a written consent was obtained from each of them.

Ethical approval was obtained from Bangladesh Medical Research Council (BMRC).

Five $\mathrm{ml}$ of venous blood was collected in metalfree tubes using intravenous canula from each patients and controls after overnight fasting. The blood sample was allowed to clot at room temperature for one hour, so that clotting factors could be removed from the serum. Then the blood sample was centrifuged at $3000 \mathrm{rpm}$ for 15 minutes at room temperature to extract the serum. The serum was aliquoted into the eppendorf tube and was kept at $-80^{\circ} \mathrm{C}$ until further analysis. Blood collection and serum separation were carried out in dust free environment.

Analysis of the trace element was carried out by flame atomic absorption spectrometry (Varian SpectraAA 220) according to the method of Falchuk et $a{ }^{12}$ Serum samples were diluted by deionized water by a factor of 30 . Different concentrations $(0.5$, $1.0,2.0,5.0$ and $10.0 \mathrm{mg} / \mathrm{l})$ of trace elements were used for calibration of standard graphs. Absorbances were read at $324.7 \mathrm{~nm}, 213.9 \mathrm{~nm}, 217.0 \mathrm{~nm}$ and 279.5 $\mathrm{nm}$ for Calcium $(\mathrm{Ca})$, Iron $(\mathrm{Fe})$, Lead $(\mathrm{Pb})$ and Cadmium $(\mathrm{Cd})$ respectively in the atomic absorption spectrometer (Table 1). To verify the assay accuracy and to maintain quality, the standard solutions were run for every 10-test sample. A software package (SpactrAA software) was used to calculate concentration of calcium, iron, lead and cadmium. 
The precaution for both collection and subsequent handling of serum were taken in order to avoid or minimize trace elements contamination.

Table 1. Wavelengths and optimum working range of different trace elements.

\begin{tabular}{lcc}
\hline Trace element & $\begin{array}{c}\text { Wavelength } \\
(\mathrm{nm})\end{array}$ & $\begin{array}{c}\text { Optimum working } \\
\text { range }(\mu \mathrm{g} / \mathrm{ml})\end{array}$ \\
\hline Iron $(\mathrm{Fe})$ & 213.9 & $0.01-2$ \\
Calcium $(\mathrm{Ca})$ & 324.7 & $0.03-10$ \\
Lead $(\mathrm{Pb})$ & 217.0 & $0.1-30$ \\
Cadmium $(\mathrm{Cd})$ & 279.5 & $0.02-5$ \\
\hline
\end{tabular}

Statistical Analysis. The results were expressed as mean \pm SD by using SPSS (Windows Version 11.5) software. Differences between groups means were determined by independent sample t-test. The significance level was set at $\mathrm{P}<0.05$.

\section{RESULTS AND DISCUSSION}

In this experiment the sample size was 60 (30 for schizophrenia disorder patients and 30 for control healthy volunteers). Socioeconomic data of both schizophrenic patients and controls are presented in Table 2. It was observed that most of the patients were educated up to higher secondary $(40 \%)$, unmarried $(53 \%)$ and lower middle class (in the range of 51 US\$ and 100 US\$) with mean age 30.00 \pm 5.96 years. BMI for majority of the patients was within the normal range.

Table 2. Socioeconomic condition and nutritional status of schizophrenic patients $(n=30)$ and controls $(n=30)$

\begin{tabular}{|c|c|c|c|c|}
\hline \multirow[t]{2}{*}{ Parameter } & \multicolumn{2}{|c|}{ Patients } & \multicolumn{2}{|c|}{ Control } \\
\hline & $\mathrm{n}(\%)$ & Mean \pm SD & $\mathrm{n}(\%)$ & Mean \pm SD \\
\hline \multicolumn{5}{|l|}{ Education } \\
\hline Secondary(vi-x class) & $6(20.00)$ & & $4(13.33)$ & \\
\hline Higher secondary & $4(13.33)$ & & $6(20.00)$ & \\
\hline \multirow[t]{2}{*}{ Graduate and above } & $12(40.00)$ & & $14(46.67)$ & \\
\hline & $8(26.67)$ & & $6(20.00)$ & \\
\hline \multicolumn{5}{|l|}{ Occupation } \\
\hline Service & $14(46.67)$ & & $10(33.33)$ & \\
\hline Small business & $8(26.67)$ & & $6(20.00)$ & \\
\hline Student & $2(6.67)$ & & $8(26.67)$ & \\
\hline Housewife & $6(20.00)$ & & $4(13.33)$ & \\
\hline \multicolumn{5}{|l|}{ Monthly income in US \$ } \\
\hline $0-50$ & $10(33.33)$ & & $8(25.00)$ & \\
\hline $51-100$ & $8(26.67)$ & $97.53 \pm 60.62$ & $10(31.25)$ & $109.53 \pm 70.44$ \\
\hline $101-150$ & $6(20.00)$ & & $6(18.75)$ & \\
\hline $151-200$ & $4(13.33)$ & & $4(12.5)$ & \\
\hline $201-300$ & $2(6.67)$ & & $4(12.5)$ & \\
\hline \multicolumn{5}{|l|}{ Age in years } \\
\hline $15-20$ & $2(6.67)$ & & $4(13.30)$ & \\
\hline $21-25$ & $6(20.00)$ & $30.00 \pm 5.96$ & $12(40.00)$ & $26.6 \pm 6.0$ \\
\hline $26-30$ & $6(20.00)$ & & $4(13.33)$ & \\
\hline $31-35$ & $10(33.33)$ & & $8(26.6)$ & \\
\hline $36-40$ & $6(20.00)$ & & $2(6.70)$ & \\
\hline \multicolumn{5}{|l|}{ Marital status } \\
\hline Married & $8(26.67)$ & & $10(33.33)$ & \\
\hline Unmarried & $16(53.33)$ & & $16(60.00)$ & \\
\hline Divorced & $6(20.00)$ & & $4(6.67)$ & \\
\hline \multicolumn{5}{|l|}{ BMI $\left(\mathrm{Kg} / \mathbf{m}^{2}\right)$} \\
\hline $15.5-18.4(\mathrm{CED})$ & $12(26.09)$ & & $0(0.0)$ & \\
\hline 18.5-25.0(Normal) & $32(69.57)$ & $20.26 \pm 3.04$ & $39(86.67)$ & $23.56 \pm 2.03$ \\
\hline$>25.0$ (Obese) & $2(4.35)$ & & $6(13.33)$ & \\
\hline
\end{tabular}

Serum trace element levels are presented in the Table 3. $\mathrm{Fe}, \mathrm{Cd}, \mathrm{Pb}$ and $\mathrm{Ca}$ concentrations of schizophrenia disordered patients were $8.6240 \pm$ $2.5314(\mathrm{mg} / \mathrm{l}), 1.9163 \pm 0.79313(\mathrm{mg} / \mathrm{l}), 0.9420 \pm$ $0.19516(\mathrm{mg} / \mathrm{l})$ and $46.1768 \pm 14.660428(\mathrm{mg} / \mathrm{l})$ while these were $2.8853 \pm 1.85552(\mathrm{mg} / \mathrm{l}), 1.3227 \pm$ $0.80290(\mathrm{mg} / \mathrm{l}), 1.2520 \pm 1.60049(\mathrm{mg} / \mathrm{l})$ and 54.7288 $\pm 18.6776(\mathrm{mg} / \mathrm{l})$ in control subjects respectively. From trace elements analysis, it was found that the serum concentration of trace element iron increased 
significantly $(\mathrm{p}>0.05)$ in schizophrenic patients compared to that of the controls.
There was no correlation of serum minerals with BMI, age and income of the patients (Table 4).

Table 3. Serum Trace elements level in schizophrenic patients $(n=30)$ and controls $(n=30)$.

\begin{tabular}{|c|c|c|c|c|c|c|c|}
\hline \multirow[b]{2}{*}{ Parameter } & \multicolumn{3}{|c|}{ Patient } & \multicolumn{3}{|c|}{ Control } & \multirow[b]{2}{*}{$P$-value } \\
\hline & $\mathrm{n}$ & $\%$ & Mean \pm SD & $\mathrm{n}$ & $\%$ & Mean \pm SD & \\
\hline \multicolumn{8}{|l|}{$\begin{array}{l}\text { Trace Elements } \\
\mathrm{mg} / \mathrm{l}\end{array}$} \\
\hline \multicolumn{8}{|l|}{ Iron (Fe) } \\
\hline $\begin{array}{l}0.008-0.154 \\
0.155-0.200\end{array}$ & $\begin{array}{l}4 \\
3\end{array}$ & 20.0 & $8.6240 \pm 2.5314$ & 6 & 40.0 & $2.8853 \pm 1.85552$ & $P=0.000$ \\
\hline $0.201-0.305$ & 8 & 53.3 & & 5 & 33.3 & & \\
\hline \multicolumn{8}{|l|}{ Cadmium (Cd) } \\
\hline $0.0037-0.0400$ & 6 & 40.0 & & 3 & 20.0 & & \\
\hline $0.0401-0.0600$ & 6 & 40.0 & $1.9163 \pm 0.79313$ & 6 & 40.0 & $1.3227 \pm 0.80290$ & $P=0.917$ \\
\hline $0.0601-0.0800$ & 3 & 20.0 & & 3 & 20.0 & & \\
\hline \multicolumn{8}{|l|}{ Lead (Pb) } \\
\hline $0.0028-0.025$ & 1 & 6.66 & & 2 & 13.3 & & \\
\hline $0.0251-0.070$ & 1 & 6.70 & $0.9420 \pm 0.19516$ & 5 & 33.3 & $1.2520 \pm 1.60049$ & $\mathrm{P}=0.316$ \\
\hline $0.071-0.1247$ & n.d. & n.d. & & 1 & 6.60 & & \\
\hline \multicolumn{8}{|l|}{ Calcium (Ca) } \\
\hline $0.1896-0.9830$ & 4 & 26.6 & 46.1768 & 2 & 13.3 & & \\
\hline $0.9831-1.5700$ & 8 & 53.3 & \pm & 8 & 53.3 & $54.7288 \pm 18.6776$ & $\mathrm{P}=0.379$ \\
\hline $1.5701-2.0150$ & 3 & 20.0 & 14.660428 & 5 & 33.3 & & \\
\hline
\end{tabular}

Table 4. Correlation of serum minerals with BMI, income and age of schizophrenic patients $(\mathrm{n}=30)$.

\begin{tabular}{lcccc}
\hline Parameter & Fe & Cd & $\mathrm{Pb}$ & $\mathrm{Ca}$ \\
\hline \multirow{2}{*}{ BMI $\left(\mathrm{kg} / \mathrm{m}^{2}\right)$} & $\mathrm{r}=0.693$ & $\mathrm{r}=0.118$ & $\mathrm{r}=-0.278$ & $\mathrm{r}=-0.188$ \\
& $\mathrm{p}=0.000$ & $\mathrm{p}=0.535$ & $\mathrm{p}=0.504$ & $\mathrm{p}=0.320$ \\
\hline \multirow{2}{*}{ Monthly income in US \$ } & $\mathrm{r}=0.498$ & $\mathrm{r}=0.058$ & $\mathrm{r}=-0.433$ & $\mathrm{r}=-0.085$ \\
& $\mathrm{p}=0.005$ & $\mathrm{p}=0.761$ & $\mathrm{p}=0.283$ & $\mathrm{p}=0.654$ \\
\hline \multirow{2}{*}{ Age (year) } & $\mathrm{r}=0.378$ & $\mathrm{r}=-0.335$ & $\mathrm{r}=0.524$ & $\mathrm{r}=-0.190$ \\
& $\mathrm{p}=0.039$ & $\mathrm{p}=0.070$ & $\mathrm{p}=0.183$ & $\mathrm{p}=0.314$ \\
\hline
\end{tabular}

Significance $\mathrm{p}<0.05$

In many studies it was established that patients with neurological disease had higher rate of being attacked by schizophrenia disorder. $^{13}$ A few investigators reported serum trace element level involvement in some psychotic disorders such as schizophrenia, mania, depression, anxiety etc. ${ }^{14,15}$

We have reported here the changes in serum trace element levels in schizophrenia disorder patients, and its correlation with nutritional status and socioeconomic factors. Analysis of socioeconomic information showed that schizophrenia disorder was prevalent in lower middle class, young and unmarried people, which is in good match with previous findings. ${ }^{16,17}$

Analysis of serum trace elements indicated that there was a trend of increasing serum concentrations of $\mathrm{Fe}$ and $\mathrm{Cd}$ in schizophrenia disordered patients while serum $\mathrm{Pb}$ and $\mathrm{Ca}$ concentrations were found to be decreased. But, only the serum concentration of iron was found to be increased significantly in schizophrenic patients compared to that of the controls.

\section{REFERENCES}

1. Goldner, E.M., Hsu, L., Waraich, P. and Somers, J.M. 2002. Prevalence and incidence studies of schizophrenic disorders: a systematic review of the literature. Canadian J. Psychiatry 47, 833-43.

2. Mertz, W. 1981. The essential trace elements. Science 213, 1332-1338.

3. Muralidhar, L.H. 2004. Serum trace element levels and the complexity of inter element relations in patients with parkinson' disease. J. Trace Elem. Med. Biol. 18, 163-171. 
4. Bennett and Plum, W.B. 1977. Saunders and Company, Philadelphia, Textbook of Medicine, 20th Ed., 1996, p 69; \& Comprehensive Psychiatry 18, 595-598,

5. Arena, Drew, Poisoning. 1995. Toxicology-SymptomsTreatment, Fifth Edition. Charles C. Thomas-Publisher, Springfield Il, 1986; \& Merritt's Textbook of Neurology, 9th Ed., Williams and Wilkins, Baltimore \& Clinical Management of Poisoning, 3rd Ed. pp. 753

6. Tudor, R., Zalewski, P.D. and Ratnaike, R.N. 2005. Zinc in health and chronic disease. J. Nutr. Health Aging. 9, 45-51.

7. Peralta, V., Cuesta, M.J., Mata, I., Serrano, J.F., PerezNievas, F. and Natividad, M.C. 1999. Serum iron in catatonic and noncatatonic psychotic patients. Biol. Psych. 45, 788-90.

8. Weiser, M., Levkowitch, Y., Neuman, M. and Yehuda, S. 1994. Decrease of serum iron in acutely psychotic schizophrenic patients. Int. J. Neurosci. 178, 49-52.

9. Tuthill, R.W. 1996. Hair lead levels related to children's classroom attention deficit behavior. Arch Enviro. Health. 51, 214-220.

10. Yanik, M., Kocyigit, A., Tutkun, H., Vural, H. and Herken, H. 2004. Plasma manganese, selenium, zinc, copper, and iron concentrations in patients with schizophrenia. Biol Trace Elem Res. 98, 109-17.
11. Lidow, M.S. 2003. Calcium signaling dysfunction in schizophrenia: a unifying approach. Brain Res. Rev. 43, 285,

12. Falchuk, K.H. et al. 1993. A Euglena gracilis zinc endonuclease. Biochem. 32, 1204-11.

13. Hansen, M.S., Fink, P., Sondergaard, L. and Frydenberg, M. 2005. Mental illness and health care use: a study among new neurological patients. Gen. Hosp. Psychiatry 27, 119-24.

14. Tiwari, S.C., Lal, N., Trivedi, J.K. and Varma, S.L. 1989. Relationship of immunoglobulins with the number \& duration of schizophrenic episodes. Indian J. Med. Res. 90, 229- 32 .

15. Bergquist, J., Bergquist, S., Axelsson, R. and Ekman, R. 1993. Demonstration of immunoglobulin $G$ with affinity for dopamine in cerebrospinal fluid from psychotic patients. Clin. Chim. Acta. 217, 129-42.

16. Mullick, M.S. 2002. Somatoform disorder in children and adolescents. Bangladesh Med. Res. Counc. Bull. 28, 112-22.

17. Bates, M.S., Rankin-Hill, L., Sanchez-Ayendez, M. and Mendez-Bryan, R. 1995. A cross-cultural comparison of adaptation to chronic pain among Anglo-Americans and native Puerto Ricans. Med. Anthrop. 16, 141. 